\title{
Cultivating a Process Approach to Writing: Student Experiences in a Developmental Course
}

\author{
James Pacello \\ Berkeley College
}

\begin{abstract}
Many developmental writing courses in colleges focus on teaching students isolated skills, with little emphasis on how such skills are applicable to the actual process of writing. This article focuses on capturing the perspectives of students enrolled in a developmental writing course designed around an explicit process-oriented pedagogy. The instructor assigned metacognitive tasks and aimed to be transparent with students about the purpose of all course activities and assignments. The findings point to the various ways students can learn to value and use a process approach when writing. The paper concludes with recommendations for helping both instructors and institutions foster a processoriented writing culture in college classrooms. It also points to future research possibilities.
\end{abstract}

Keywords: developmental writing, metacognition, transparency, writing studies, college writing

One assumption many faculty members might make about the act of writing is that students view and treat it as a recursive process. As a review of research on college writing reveals, the habits, skills, and actions associated with the writing process, such as planning, considering audience and context, researching, drafting, and revising, are key aspects of successful writing in college classrooms (Beaufort, 2007; Council of Writing Program Administrators, National Council of Teachers of English, \& National Writing Project, 2011; Cox, 2009; Rose, 2012). However, many students begin college not recognizing the need for a robust process-oriented approach to writing.

Researchers have found that very often college students do not approach writing systematically and instead rely on methods of writing that they have used in the past, neglecting to take ownership over their own learning (Ambrose, Bridges, DiPietro, Lovett, \& Norman, 2010). Conley (2005) found that when students enter college, they often do not allot much time and effort to working on writing assignments. He argued that this was in part because students often have been taught by high school teachers who have little time to provide feedback on student writing and often must stress formulaic approaches to writing due to standardized writing rubrics. Unfortunately, if students do not recognize the need for a process-oriented mindset and approach to college writing, it seems unlikely that they will be equipped to navigate the complex writing demands of college classrooms.

Such limited views about writing seem likely to be prevalent in students who are deemed to be academically underprepared when they enter college (Rose, 2012). These students often participate in developmental or remedial education programs (Grubb \& Gabriner, 2013). The programs often include coursework created to help students develop college level reading, writing, and math skills. According to the Community College Research Center (2014), "Federal data indicate that 68 percent of community college students and 40 percent of students at open-access four-year colleges take at least one remedial course" (p. 1). Unfortunately, Grubb and Gabriner (2013) found that many developmental reading, writing, ESL, and math classrooms emphasize a "remedial pedagogy" approach in which the emphasis is on teaching isolated skills, such as grammar and punctuation, with limited focus on how such skills are applicable to other contexts (p. 52). This kind of pedagogy is unlikely to help students adapt a flexible, process approach to writing. Developmental writing courses are an excellent place to set the stage for students to begin rethinking their beliefs about and approaches to writing. Students can then build upon this learning throughout the remainder of their education. 
This article uses aspects of a larger qualitative research study I conducted (Pacello, 2015). It focuses on a developmental writing course I taught. The original study drew upon teacher-research, phenomenological, and case study research traditions (Cochran-Smith \& Lytle, 1993; Creswell, 2007). It examined the ways students in a developmental writing course discussed developing their beliefs about and approaches to writing. It also explored how they articulated using what they learned when they wrote for other courses. Using portions of that study, this article addresses the following research question: In what ways (if any) does taking a developmental writing course designed around an explicit and transparent process-oriented pedagogy help students alter their beliefs about and approaches to writing? To address this question, I analyzed the ways students articulated how specific assignments, activities, and other elements of the course's overall design helped them develop as writers.

\section{Theoretical Framework}

Researchers from the fields of literacy, writing studies, and developmental education have argued that students can benefit from being taught to rethink some of their prior writing beliefs. For instance, Rose (2012) explained that a central goal he had when teaching developmental writing courses was to "change the model of writing my students carried in their heads" (p. 137). Students need to learn about the recursive qualities of effective writing. As Downs and Wardle (2007) have found, students often perceive writing largely in terms of drafting, neglecting to consider the "larger series of events" of the writing process such as exploring ideas and researching (p. 563). Students also do not always recognize how essential revision is to effective writing. Downs (2015) contended that students often associate it with poor writers. He asserted that they need to be taught that revising is "a sign and a function of skilled, mature, professional writing and craft" (Ch. 4.4). This understanding can help students recognize that writing takes a great deal of time and attention and that even experienced writers partake in a complex process that includes extensive revisions (Downs, 2015). Instructors can play a pivotal role in helping students "revise their writing process" (Rose, 2012, p. 137).

Developmental writing courses are often not designed in ways that foster a process-oriented mindset in students. Rose (2012) has asserted that there are "deep-rooted erroneous beliefs about learning that shape most remedial programs" (p. 12). He explained that very often such courses emphasize a "skills-and-drills" approach (p. 126). Alternative approaches are necessary. Grubb and Gabriner's (2013) work speaks to this need. They discussed a large-scale qualitative research study examining developmental education classrooms, including writing courses. Their findings suggested that a writing process pedagogy, as opposed to a "remedial pedagogy" approach, is more effective in helping students to develop the recursive, process-oriented mindset so crucial to mastering the skills and habits of college writing (Grubb \& Gabriner, 2013, p. 52). The researchers have discussed this approach in detail, explaining that it often includes "first, brainstorming ideas, then writing freely without undue concern for correctness, and then a crucial process of revision and editing (sometimes by peers or peer groups, sometimes by instructors) and creating multiple drafts" (p. 96).

Although writing textbooks sometimes discuss writing in terms of process, the complex, recursive dimensions of composing still might not be evident to students unless a course is designed to have them directly experience this process and reflect upon it. The course under study was designed with the assumption that concrete guidance and practice can help students reexamine their prior beliefs and influence their writing approach.

Journal of the Scholarship of Teaching and Learning, Vol. 19, No. 2, March 2019. josotl.indiana.edu 


\section{Methodology}

\section{Instructional Approach}

I explicitly designed the course to foster in students a process-oriented writing approach. This design was consistent with concepts about writing instruction that have been promoted by a variety of researchers and educational organizations (Council of Writing Program Administrators, et al., 2011; Grubb \& Gabriner, 2013). I also consciously sought to be transparent with the students about my rationale for all assignments and activities. Winkelmas (2013) has found that transparency in classrooms can enhance learning by helping students better understand the purpose of assignments and how they are connected to the goals of a course. Each major assignment was sequenced over several weeks. To emphasize the writing process, this sequencing included explicit discussions of each stage of the writing process, generating ideas through freewriting, raising questions about assignments, conducting research, and discussing the various purposes of and contexts for different types of writing. When I incorporated instruction in grammar and/or punctuation into the course, I emphasized that this knowledge was an important tool of the writing process that could help students make their writing more audience centered and easy to read.

Various forms of formative feedback were built into the course design. For instance, students needed to provide feedback to each other in small groups. This aspect of the course was designed to help students develop the ability to consider whether their meaning is clear to a reader, emphasizing writing "as a form of communication among people and as the expression of ideas" (Grubb \& Gabriner, 2013, p. 96). The rationale for this requirement was shared with students, emphasizing what role reader input can play in the writing process. Clear guidelines were given for how to provide helpful feedback, including beginning with a positive statement and giving concrete feedback.

Additionally, students submitted their final assignment to the college's online tutoring service, which was staffed by professional tutors. This requirement was enacted to help students become more conscious of a process approach to writing. After submission, students received emailed feedback on their work from the tutoring center. This approach was aligned with prior research showing that developmental courses can provide students with a valuable form of assistance when they integrate meaningful interactions between students and support services such as tutoring (Callahan \& Chumney, 2009; Grubb \& Gabriner, 2013).

After this stage, students had a short conference session with me to discuss their plans for integrating the feedback into their finished product. During that conference I also helped students prioritize what they should focus on during the revision stage of the writing process. Similar to the peer feedback sessions, students were given a clear rationale for why this task was included in the course and how it related to the writing process. I explained to them that I designed the tutoring and conference requirement with the intention of introducing them to a resource they could use as part of their writing process for all their coursework.

An integral strategy incorporated into the course was reflective tasks aimed at improving student metacognition and helping them become conscious of their evolving writing process. As Ambrose et al. (2010) have asserted, two crucial dimensions of metacognition are the ability to monitor one's learning and the ability to reflect on and evaluate one's learning. In the reflective blogs that students wrote for the course, they articulated the steps they took as they approached the assignments and what they believed they had learned about their own evolving approaches to writing. They also assessed what they believed they still needed to work on as writers. Students also created an electronic portfolio collection of their own work. On the welcome page of their portfolio, they introduced the written work they completed in the course and presented their thoughts about what they had learned about writing by producing these written artifacts. 


\section{Research Site and Participants}

The study was conducted at a private urban college in the Northeast. The institution operated on a quarter system and offered Bachelor's and Associate's degrees. The focus of the study was on two non-credit developmental writing classes, which I will refer to as Developmental Writing. They met for four credit hours per week. The maximum number of students for all developmental courses was twenty. For at least half of those hours, the classes met in a computer lab. Students were required to take this course based on the results of the ACCUPLACER exam, which determined whether they needed developmental coursework in reading, writing, and/or math. Students needed to complete the course with the overall grade of $\mathrm{C}$ or above.

For this paper, I focused on the perspectives of six of the eight student participants who participated in the study. The participants that I included spoke most directly to the paper's research question. One participant was drawn from a course section I taught in the summer of 2013. The other participants were drawn from a section I taught in the fall of 2013. The limited number of students helped me to get an in-depth understanding of student experiences because I was able to closely examine multiple forms of data revolving around the participants. I asked students to volunteer to be in the study via email after they had completed the course and received a final grade. They were provided with detailed consent forms, and I explained to them the purpose of the study. The participants selected represented the range of ages of many developmental classrooms and their majors reflected several of the college's degree programs. All participant names are pseudonyms. Information was derived from student self-reporting. See table 1.

\section{Table 1. Participants}

\begin{tabular}{|l|l|l|}
\hline Name & Age & Major \\
\hline Adam & 18 & Information Technology \\
\hline Amesha & 22 & Business Administration Management \\
\hline Bruno & 24 & Business \\
\hline Dana & 38 & Health Management \\
\hline Gideon & 33 & Business \\
\hline Heidi & 21 & Fashion Marketing and Management \\
\hline
\end{tabular}

\section{Data Collection and Analysis}

The study drew upon both phenomenological and case study traditions in qualitative research. Consistent with phenomenological traditions, interviews were the primary mode of data collection as I gathered student perceptions of taking the course. This method was guided by Patton's (1990) notion that "qualitative interviewing begins with the assumption that the perspective of others is meaningful, knowable, and able to be made explicit" (p. 278). Additionally, I drew from case study traditions by collecting extensive data in the form of field note reflections and observations of my own experiences in the classroom and written work students produced during the developmental course (Creswell, 2007). This process helped me triangulate the data because the various sources of information I collected enabled me to corroborate and enrich what I learned from participants during the interviews (Creswell, 2007).

My role as both the instructor and the researcher was aligned with Goswami and Stillman's assertions about teacher research, "Teachers know their classrooms and students in ways that outsiders can't” (as cited in Cochran-Smith \& Lytle, 1993, p. 19). As their instructor, I developed a 
rapport with participants that might not have been possible if I were a stranger. I explained to them that their honest responses to the interview questions would be helpful to me and other professors who were aiming to improve the design of writing courses. I was also able to document in a researcher journal important observations I made as the course unfolded.

Using three different data collection strategies, I asked participants at three different times what they believed were some of the writing habits and skills necessary for success in college. The first of these data sources was a writing inventory given to students in the class at the beginning of the quarter in which they took the course. Participants were also asked a question about their beliefs during the first interview, which was conducted shortly after they had completed the course. Finally, they were asked a variation of this same question during the second interview, which took place during the second half of the quarter after they had completed the developmental course. Participants were also asked questions about which assignments and activities from the developmental course they believed helped them become better college writers.

I also gathered short reflective blog posts students wrote throughout the course about their own writing process. In discussing documents as a form of data, Merriam (1998) has explained that "because they exist independent of a research agenda, they are nonreactive, that is, unaffected by the research process" (p. 126). When participants produced the documents I analyzed, they were still enrolled in my class, and thus not yet specific participants in the study, so their comments on these sources were not affected at all by the participants' knowledge that they were part of a study.

Finally, the welcome page of the electronic portfolio was a data source that helped me to understand what participants felt they had learned through taking the course. This short written assignment happened at the end of the quarter, so it was helpful to give me insight into their experiences with the course as it came to a close. I used the data that emerged in the electronic portfolios and reflective blogs as forms of comparison and contrast to the ways students discussed their writing process during the interviews.

During data analysis, I engaged in a process of coding and "discovering themes and subthemes" (Ryan \& Bernard, 2003, p. 85). To arrive at these themes, I used a combination of the views and language of the participants ("emic") and my own interpretive perspective ("etic") on the phenomenon under study (Creswell, 2007, p. 72). As part of the coding process, I engaged in a process of peer debriefing to help me refine my thinking about what was emerging in the data (Creswell, 2007). Using various forms of data helped me to interpret the nuances of the phenomenon of students' rethinking their prior writing beliefs and evolution of their writing processes through course participation. All in all, multiple methods were used to maximize the validity of the findings. These methods included triangulation of data, a researcher journal, and peer debriefing (Creswell, 2007; Miles and Huberman, 1984).

\section{Findings}

An important element of this study was to examine the ways participants discussed a range of assignments, tools, and structural aspects of the course in relationship to their emerging or evolving understanding of writing. The findings pointed to the multiple ways students might be taught to acquire process-oriented beliefs and approaches to writing. This section is arranged around several prominent themes that emerged during data analysis about the course design and how it helped foster a process-oriented mindset in participants. 


\section{Writing As a Means of Thinking Through Ideas}

Adam, Amesha, Dana, and Gideon discussed the ways elements of the course design helped them perceive writing as a process of thinking about and exploring ideas. For instance, during his first interview, Adam described the blog tasks as giving him "the freedom to bring your idea to life." Likewise, Amesha described working on her ePortolio welcome page as giving her the opportunity to "explore" and "expand" her ideas. Also connected to the idea of writing as a means of thinking, Dana explained during her first interview, "I think [freewriting is] a good writing tool" because "eventually you find you get a[n] idea that you could really develop" when you do it. She also stated that freewriting can help generate thoughts which can then "evolve."

Gideon most vividly discussed the course in relationship to the notion of writing as a process of thinking. He explained during the first interview:

One of the things I enjoyed about the class first of all was the fact that you had time to think and write stuff through. My impression was always, of writing was... write this now...I came into the class with those expectations...I always thought writing was you kind of have an assignment pushed in front of you and you write it there and you are timed.

Based on his account about his prior experiences with writing compared to his experiences in the class, it can be inferred that the way the writing assignments were designed in the course, moving sequentially and over several weeks, seemed to challenge Gideon's prior writing experiences and the beliefs about writing which they engendered. Like some of the other participants, on the writing inventory he completed at the beginning of the quarter, there was no evidence that he believed writing is a recursive process. His responses on that document indicated his belief that "proper grammar and punctuation are key elements to being a successful college student." In contrast, his interview response suggested a significant shift in perception in which he was linking writing to thinking.

\section{Writing in Stages}

Bruno and Dana provided strong evidence of how the course activities emphasizing the stages of the process helped influence their beliefs about writing. For example, Bruno reported that it was helpful to require students to submit first drafts due prior to the deadline for submitting the final product because "You can improve, so it's not just one grade and you're out. So, you can always improve." He appeared to value the role of drafting and then revising in the writing process.

Like Bruno, Dana discussed the way the overall design of the course helped her learn to value the stages and habits of process-oriented writing. For instance, on her first reflective blog post after having taken her first major writing assignment for the class through all the stages of the writing process, she discussed what she had learned about herself as a writer, explaining, "I realized in writing it is beneficial to write in steps or sections, it is a process." Later in the quarter on her portfolio welcome page when she was asked to write a reflection on her learning in the course, Dana wrote that she had learned to apply the writing process to various written tasks. She explained:

I have employed the techniques [of the writing process] when writing the works enclosed in my e- portfolio... As the weeks elapsed this quarter, the process became easier to engage, and I observed my writing got more grammatically accurate and the flow of my content seems more logical. In writing my last essay, I found that I kept going back to the process, and realized that revising is critical in writing. 
Dana's comments focused not only on the grammatical components of her writing, but also on the flow and logic of her writing. Her comments also suggested a growing awareness of the importance of revision. Because she discussed these ideas in relationship to what she believed the course had helped her attain, it was evident that she viewed her development as being connected to the course's writing process emphasis.

\section{Peer Feedback and the Writing Process}

Several participants connected the peer feedback workshops to their evolving approaches to revising and proofreading their work because they were able to look at their writing from the perspective of a reader. For instance, Heidi felt that the process was helpful because "other people could see...if something could be added or something could be taken away." Elsewhere in the data, on a reflective blog post Adam stated that having peers review his writing helped him "perfect my writing even more." Additionally, on his second blog post, Gideon wrote, "The fear I used to have for my writing not being clear and concise has been replaced by enthusiasm to see what people think of my ability to write." His comment suggests that the feedback sessions helped him to value receiving reader input on his work.

Dana's commentary provided an interesting contrast with the perspectives of several other participants because she focused on the role of the feedback provider. She discussed some of the benefits of reviewing her classmates' work and providing them feedback. She explained that the activity was helpful because she had the chance to "see how others write." She also indicated that through providing feedback, a writer can become more "mindful" of her own mistakes. Building on this idea in the first interview, she explained:

So now I'm conscious [of] the leaving of time so that I could proofread the essay because you know from reading [the work of others], you know there's words in there or the sentence's structure... That's not the way the person speaks, so you know it had to be an error. Had they read it prior to submitting it, they would have caught it.

Dana's comments suggest that she perceived providing feedback to others helped her become more aware of the need to engage her own work attentively. It seemed obvious to her when work had not been carefully reviewed, thus reinforcing the value of having a process-oriented mindset about writing.

\section{Online Tutoring and the Writing Process}

Several participants explained that the online tutoring service helped raise their awareness of writing issues they had not known about or had overlooked. For instance, Bruno, a non-native English speaker, explained that he liked having his mistakes pointed out to him that he had not been able to detect on his own, especially because "the punctuation in English and Portuguese is different." Heidi reported that the tutor helped her find "many mistakes I didn't even realize." Elaborating, she explained that the tutor helped her understand when her final assignment was "using too much information" from the research and not enough of her own ideas. Dana articulated on her third blog post that using available resources is an important part of becoming a better writer. She explained, "Getting into the habit of having a critical eye review and comment on the paper will only streamline and crystalize your view point." In these instances, participants appeared to believe that the service played a valuable role in assisting them with editing and revising, important aspects of a process approach to writing. 


\section{Discussion}

Multiple participants were able to articulate how specific assignments, tasks, and other elements of the course design helped them develop a process approach to writing. The explicit and transparent way the course activities were designed and the emphasis on metacognition and reflection likely played a role in helping students develop an awareness of the evolution of their writing skills. The concrete emphasis on the process of writing also seemed to help participants recognize the connections between writing and exploring ideas. These findings are important because research has suggested that students sometimes misperceive why their professors assign certain kinds of activities and assignments (Cox, 2009). As Ambrose et al. (2010) have asserted and this study further affirms, effective instruction should include transparently emphasizing what is valued in the classroom and why. Transparency can aid in both short and long-term learning (Winkelmes, 2013).

The explicit discussions in the class about why each stage of the writing process is valuable for effective written communications across contexts, the short metacognitive reflective writing tasks, and the frequent use of the language of writing process likely helped participants perceive the importance of the approach. This awareness could be beneficial to students because it can help them begin to become conscious of using a systematic and strategic approach to writing. As Beaufort (2007) has contended, students encounter a variety of genres, practices, and tasks across disciplines and classes. If they do not begin developing a process-oriented mindset and approach early in their education, they are unlikely to be able to effectively navigate the diverse writing expectations of college courses.

The peer feedback sessions appeared to play a pivotal role in helping students develop a process-oriented approach to writing. It was beyond the scope of this study to analyze the quality and usefulness of feedback students receive from their classmates versus the quality of feedback they receive from other feedback resources such as their professors or tutors. However, regardless of the quality of feedback provided, there is a value to students participating in peer feedback workshops because doing so helps them consider their writing from the perspective of a reader. It also helps instill in them the idea that writing goes through multiple stages of development that includes receiving formative feedback.

It was also evident in the data that the online tutor feedback requirement helped multiple participants experience writing as a recursive process as opposed to something that happens quickly and without stages of development. These findings are important because, as Conley (2005) has found, many students begin college with limited knowledge of the time and effort it takes to complete writing assignments. The tutor feedback element of the course underscored Downs's (2015) assertions about the centrality of revision to effective writing. It also equipped students with a feedback tool they could continue to use beyond the developmental course.

\section{Recommendations}

\section{Recommendations for Instruction}

Although this study focused on a stand-alone developmental writing course, many of the following recommendations are applicable to a variety of writing course formats, including supplemental support programs that link developmental work to credit-bearing first-year composition courses. Instructors teaching first-year students how to write for college should repeatedly emphasize the idea that writing is a process regardless of the context. They should also engage students in discussions and activities focusing on how writing tasks, practices, and genres will often vary significantly across disciplines and classes. When faculty members acknowledge such variations in college classes, they can help students recognize that the recursive dimensions of the writing process can be flexibly applied

Journal of the Scholarship of Teaching and Learning, Vol. 19, No. 2, March 2019.

josotl.indiana.edu 
to the composition process across courses. Students might otherwise perceive the writing process as being applicable only to their writing class.

In order to emphasize and make the writing process concrete and to give students practice applying it, written assignments should be transparently built around recursive writing stages. The process should include time for students to receive feedback from a variety of sources (peer, tutor, and instructor). Faculty should share their rationale for including such activities in a class. It is important for faculty members to articulate what each stage of the writing process often entails even when they might believe they are stating what is obvious. Instructors should also give students regular opportunities to reflect on their own writing so that they become mindful of their evolving approaches to writing.

Although it is critical that faculty teaching developmental and first-year writing courses begin to help students develop a process-oriented approach to writing, this approach needs to be cultivated well beyond a student's first semester. Colleges need to do more to create contexts in which faculty in different disciplines are engaged in a dialogue with faculty who teach writing. Such collaborations can create opportunities for faculty across the curriculum to learn ways of incorporating the writing process explicitly into their writing assignments. For instance, they might design assignments that carefully scaffold the writing process, which can include time for planning, discussing an assignment's purpose, peer feedback, reflections on process, and/or a tutoring requirement to aid in revision. Doing so can help create a process-oriented writing culture that is college wide.

\section{Limitations and Recommendations for Future Research}

This paper relied on qualitative research methods using a limited number of participants. There is a need for longitudinal research using mixed methods approaches to help researchers examine whether students transfer what they learn about the writing process in developmental courses when they write for courses across the curriculum and to what extent they do so. Such examinations can also help determine which elements of writing are the most essential to cover in developmental courses and which elements might be best covered in more advanced writing courses.

It is also important for researchers to examine what types of revisions students make to their work after they have completed a draft. Although the findings of this study suggested that students were using a process approach to their writing, it did not address the quality and nature of the revisions students were making to their assignments after receiving feedback. Future research should systematically analyze the ways students revise their written work during and after completion of developmental writing courses.

Additional research also needs to be conducted to find out more about how to help students obtain the tools, skills, and habits necessary for success in navigating the variety of writing demands they encounter. This kind of inquiry can also help faculty and policymakers in colleges understand how demands change and increase and how writing development can continue to be supported beyond first-year course work. Colleges cannot rely on individual writing courses alone to improve the writing abilities of students. This process needs to be a college-wide effort.

\section{Acknowledgments}

I would like to thank my professors, Alisa Belzer, Erica Boling, and Susan Bickerstaff, who played pivotal roles in advising me throughout the development of the larger study that served as the basis for this paper. I would also like to thank my former classmates, Jennifer Renner Del Nero and Jessica Darkenwald-DeCola, for providing valuable feedback. Finally, thank you to the students who agreed to be participants in the study.

Journal of the Scholarship of Teaching and Learning, Vol. 19, No. 2, March 2019.

josotl.indiana.edu 


\section{References}

Ambrose, S.A., Bridges, M.W., DiPietro, M., Lovett, M.C., \& Norman, M.K. (2010). How learning works: Seven research-based principles for smart teaching. San Francisco, CA: Jossey-Bass.

Beaufort, A. (2007). College writing and beyond. Logan, Utah: Utah State University Press.

Callahan, M.K. \& Chumney, D. (2009). Write like college: How remedial writing courses at a community college and a research university position at-risk students in the field of higher education. Teachers College Record, 111(7), 1619-1664.

Cochran-Smith, M. \& Lytle, S.L. (1993). Inside/Outside: Teacher research and knowledge. New York: Teachers College Press.

Community College Research Center. (2014). What we know about developmental education outcomes. Retrieved from http:/ / ccrc.tc.columbia.edu/ media/ k2/attachments/what-we-know-about-developmentaleducation-outcomes.pdf

Conley, D. (2005). College knowledge: What it really takes for students to succeed and what we can do to get them ready. San Francisco, CA: Jossey-Bass.

Council of Writing Program Administrators, National Council of Teachers of English, \& National Writing Project. (2011). Framework for success in postsecondary writing. Retrieved from http://wpacouncil.org/files/framework-for-success-postsecondary-writing.pdf

Cox, R. (2009). The college fear factor: How Students and professors misunderstand one another. Cambridge, MA: Harvard University Press.

Creswell, J.W. (2007). Qualitative inquiry and research design: Choosing among five approaches (2nd ed.).Thousand Oaks, CA: Sage Publications, Inc.

Downs, D. (2015). Revision is central to developing writing. In L.A. Kassner \& E. Wardle (Eds.) Naming what we know: Threshold concepts of writing studies. Boulder, CO: University Press of Colorado.

Downs, D. \& Wardle, E. (2007). Teaching about writing, righting misconceptions: (Re)envisioning "First-year composition" as "Introduction to writing studies." College Composition and Communication, 58 (4), 442-584.

Grubb, W.N. \& Gabriner, R. (2013). Basic skills education in community colleges: Inside and outside of classrooms. New York, NY: Routledge.

Merriam. S. (1998). Qualitative research and case study applications in education. San Francisco, CA: JosseyBass Publishers.

Miles, M. B. \& Huberman, A. M. (1984). Drawing valid meaning from qualitative data: Toward a shared craft. Educational Researcher, 13(5), 20-30. 
Pacello

Pacello, J. (2015). Fostering a discourse of process: A qualitative study of student perspectives on a developmental college writing course (Doctoral dissertation, Rutgers University).

https://doi.org/doi:10.7282/T3KP840Z

Patton, M.Q. (1990). Qualitative evaluation and research methods ( $2^{\text {nd }}$ ed.). Newberry Park. CA: SAGE.

Rose, M. (2012). Back to school: Why everyone deserves a second change at education. New York, NY: The New Press.

Ryan, G.W. \& Bernard, H.R. (2003). Techniques to identify themes. Field Methods, 15(1), 85-109.

Winkelmes, M. (2013). Transparency in teaching: Faculty share data and improve students' learning. Liberal Education, 99(2), 48-55. 